\title{
Cytogenetic characterization of Hypostomus nigromaculatus (Siluriformes: Loricariidae)
}

\author{
Marceléia Rubert ${ }^{1}$, Cláudio H. Zawadzki ${ }^{2}$ and Lucia Giuliano-Caetano ${ }^{1}$
}

Hypostomus is the most speciose genus in the family Loricariidae, with approximately 120 species. These fish show a wide morphological and color variation, which hinders the identification of species, mainly of widely distributed representatives. The aim of this study was to contribute to the current knowledge on cytogenetic features of Hypostomus nigromaculatus. Three specimens of H. nigromaculatus, collected in two tributaries of rio Tibagi, Paraná, and in Cachoeira de Emas, rio MogiGuaçu, São Paulo, the latter being the type locality of $H$. nigromaculatus, were studied. Chromosomal preparations were submitted to Giemsa staining, silver nitrate impregnation, C-banding and CMA and DAPI fluorochromes staining. All samples presented $2 \mathrm{n}=76$, but the rio Mogi-Guaçu sample differed from those from tributaries of rio Tibagi in relation to karyotype formulae, distribution and composition of heterochromatin, and NOR location. The silver nitrate staining revealed the presence of multiple Ag-NORs for all samples, but with differences on the location on chromosomes. $\mathrm{CMA}_{3}$ staining reveled bright signals equivalent to NOR-bearing chromosomal segments; such sites were characterized by negative, i.e. unstained, marks after DAPI staining. The pattern of heterochromatin distribution was distinctive among samples from rio Mogi-Guaçu and tributaries of rio Tibagi. The differences observed between the sample from rio Mogi-Guaçu and the ones from tributaries of rio Tibagi allow us to suggest that these samples are presently isolated. Further analyses are necessary to ascertain whether such isolation refers to distinct populations or characterizes true different species.

O gênero Hypostomus é um dos mais especiosos na família Loricariidae, tendo aproximadamente 120 espécies. Apresenta uma ampla diversidade quanto ao padrão de coloração e morfologia, o que dificulta a identificação de determinadas espécies, principalmente aquelas com ampla distribuição geográfica. Para isso os dados obtidos neste trabalho contribuem para os estudos citogenéticos de Hypostomus nigromaculatus. Foram analisados três exemplares de H. nigromaculatus de afluentes do rio Tibagi, Paraná e Cachoeira de Emas, rio Mogi-Guaçu, São Paulo, sendo esta última, a localidade tipo de H. nigromaculatus. Os cromossomos foram submetidos à coloração convencional (Giemsa), impregnação por nitrato de prata, bandamento-C e coloração com os fluorocromos $\mathrm{CMA}_{3}$ e DAPI. Todos os exemplares apresentaram $2 \mathrm{n}=76$, no entanto com diferença quanto às fórmulas cariotípicas, distribuição e composição da heterocromatina. O nitrato de prata detectou RONs múltiplas para as amostras, porém com diferenças quanto à localização nos cromossomos. A coloração com fluorocromo CMA foi correspondente aos cromossomos Ag-RONs, na coloração com DAPI foram observadas bandas negativas, ou seja, não coradas. O padrão de distribuição da heterocromatina foi diferente para as amostras do rio Mogi-Guaçu e dos tributários do rio Tibagi. As diferenças observadas entre as amostras de rio Mogi-Guaçu e afluentes do rio Tibagi permitem-nos sugerir que essas amostras estejam atualmente isoladas. Outras análises são necessárias para determinar se as amostras analisadas são populações distintas ou trata-se de espécies diferentes.

Key words: karyotype evolution, Nucleolus organizer region, Heterochromatin, Hypostominae.

\section{Introduction}

Hypostomus is one of the most specious genera in the subfamily Hypostominae, with approximately 120 nominal species (Weber, 2003). These fish occur almost everywhere in the East Andean tropical and temperate South America, inhabiting an array of aquatic habitats, although being usually found in running water systems (Montoya Burgos, 2003).
Systematists have found it very difficult to identify species in this group, due to the large number of species belonging to the genus and due to their large intra-specific variation of both morphology and color pattern (Reis et al., 1990). Due to this large variation, molecular studies using allozymes and mtDNA have been carried out to help species identification and determine the phylogenetic relationships of some species within the genus (Zawadzki et al., 2001, 2005).

'Departamento de Biologia Geral, Universidade Estadual de Londrina, CCB. 86051-990 Londrina, Paraná, Brazil. giuliano@uel.br ${ }^{2}$ Departamento de Biologia, Universidade Estadual de Maringá/Nupélia, Av. Colombo 5790, G90, 87020-900 Maringá, PR, Brazil. 
In relation to the diploid number, karyotype macrostructure and chromosomal banding, this group can be considered non-conservative (Artoni \& Bertollo, 1996; Alves et al., 2003). Chromosomal rearrangements have played a major role in the karyotype evolution of Hypostominae (Artoni \& Bertollo, 1996), including a case of polymorphism related to the presence of supernumerary chromosomes (Scavone \& Júlio Jr., 1994). To date, most of cytogenetic data about the genus Hypostomus are restricted to diploid number, karyotype formulae and NOR location. The diploid number range from 52 in H. emarginatus (Artoni \& Bertollo, 2001) to 84 in Hypostomus sp. 2- rio Perdido NUP 4249 (S. S. Cereali, pers. commun.). The number of NOR-bearing chromosomes varies from 2 to 8 chromosomes, usually carrying terminal rDNA sites on short or long arms (Artoni \& Bertollo, 2001; Alves et al., 2005).

In the present study, specimens of Hypostomus nigromaculatus (Schubart, 1964) from rio Mogi-Guaçu, Cachoeira de Emas, the type locality of this species, and from two other localities in the rio Tibagi, were cytogenetically examined in order to characterize a possible geographic variation in this species. Furthermore, these represent the first cytogenetic data on $H$. nigromaculatus.

\section{Material and Methods}

Hypostomus nigromaculatus is widespread throughout Middle and Upper Paraná river basin in South America, being Cachoeira de Emas, rio Mogi-Guaçu, a tributary of rio Grande, in the city of Pirassununga, state of São Paulo, its type locality. Fifteen specimens of Hypostomus nigromaculatus were collected at three different localities: Cachoeira de Emas - rio Mogi-Guaçu, (NUP 5071, three males and four females), in Pirassununga, São Paulo, Brazil; ribeirão Três Bocas (NUP 5070, two males and three females); and ribeirão dos Apertados (MZUEL 4705, three females). The last two sites

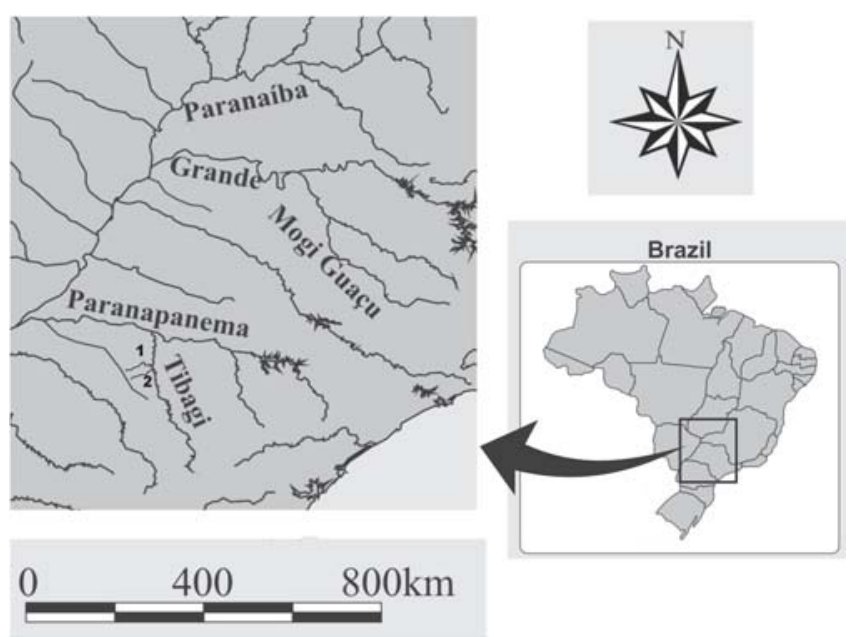

Fig.1. Hydrographic map showing rio Mogi-Guaçu, rio Tibagi, 1 = ribeirão Três Bocas and 2 = ribeirão dos Apertados (tributaries of the rio Tibagi). are tributaries of the rio Tibagi, located in the municipality of Londrina, Paraná, Brazil (Fig.1). NUP refers to the ichthyological collection of NUPELIA (NUP: Núcleo de Pesquisas em Limnologia, Ictiologia e Aqüicultura, da Universidade Estadual de Maringá, Brazil) and MZUEL refers to the ichthyological collection of Museu de Zoologia da Universidade Estadual de Londrina, Brazil.

Mitotic chromosomes were obtained according to the conventional technique of Bertollo et al. (1978). The chromosomes were classified into three groups: metacentric (m), submetacentic (sm) and subtelocentric-acrocentric (st-a), according to Levan et al. (1964). Nucleolar organizer regions were detected by silver nitrate staining (Ag-NORs) (Howell \& Black, 1980). GC- and AT-rich sites were stained with Chromomycin $\mathrm{A}_{3}\left(\mathrm{CMA}_{3}\right)$ and 4' 6-diamidin-2-phenylindole (DAPI) (Schweizer, 1976; Schmid, 1980; Christian et al., 1998). C-banding was performed to determine the pattern of heterochromatin distribution (Sumner, 1972) and chromosomes were stained with Giemsa and with the fluorochromes $\mathrm{CMA}_{3}$ and DAPI in order to verify their compositional nature.

\section{Results}

The seven specimens from rio Mogi-Guaçu showed a diploid number of $2 n=76$ and a karyotype formulae of $8 \mathrm{~m}+20 \mathrm{sm}+48 \mathrm{st}-\mathrm{a}$, with a fundamental number (FN) of 104 (Fig. $2 \mathrm{a})$. Four specimens presented a secondary constriction on long arms of up to two non-homologous and large st-a chromosomes $\left(25^{\text {th }}\right.$ and $\left.28^{\text {th }}\right)$ (Fig. 3a-I).

All specimens from both samples in tributaries of rio Tibagi presented a diploid number of $2 n=76$, with a karyotype formulae of $6 \mathrm{~m}+20 \mathrm{sm}+50 \mathrm{st}-\mathrm{a}$ and a FN equal to 102 (Fig. $2 \mathrm{~b}$ ). Three specimens showed up to three chromosomes bearing secondary constrictions on short arms of a large st-a pair $\left(16^{\text {th }}\right)$ and on long arms of another st-a chromosome $\left(27^{\text {th }}\right)$. Pictures related to the sample from Apertados are not shown in the figures, once the results were identical to those from ribeirão Três Bocas (Fig. 3b-I).

In the sample from rio Mogi-Guaçu, silver nitrate staining of the chromosomes revealed the presence of multiple AgNORs in two or three large st-a chromosomes, located at terminal position on long arms, corresponding to pairs 25 and 28. On the pair 25 , positive staining was observed in one homologous, and a size heteromorphism was detected in the pair 28 of four specimens, in agreement with the secondary constrictions, with distinct individual pattern within this sample (Fig. 3a-II).

Silver nitrate staining of the chromosomes in specimens from tributaries of the rio Tibagi showed until three stained chromosomes with marks located at terminal region on long arms of one st-a chromosome, corresponding to an element from the pair 27, and at terminal region on short arms of a sta pair (pair 16), also characterized by size heteromorphism in three specimens (Fig. 3b-II).

Staining with the fluorochrome $\mathrm{CMA}_{3}$ detected until three positively stained sites on Ag-NOR-bearing chromosomes in 
m $\mid \begin{array}{cccc}3 x & 6 x & x x & x x \\ 1 & 2 & 3 & 4\end{array}$

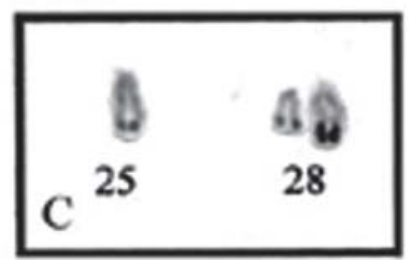

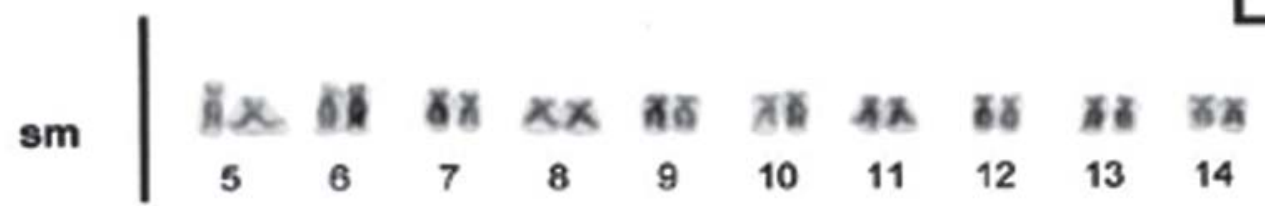
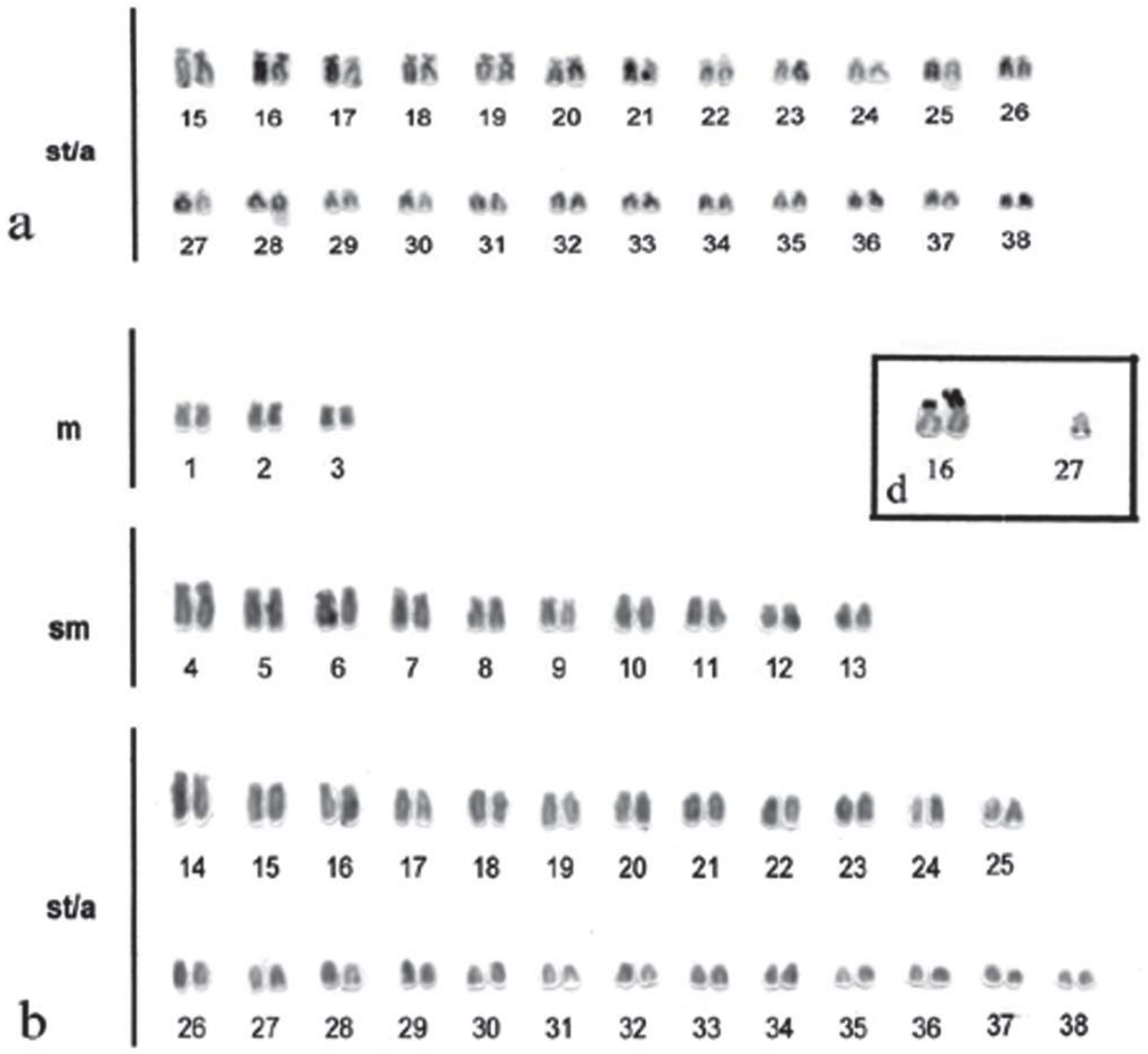

Fig. 2. Karyotypes of Hypostomus nigromaculatus with conventional Giemsa staining: a) rio Mogi-Guaçu and b) tributaries of the rio Tibagi. Ag-NOR-bearing chromosomes from rio Mogi-Guaçu (c) and tributaries of the rio Tibagi (d) are framed. 
the rio Mogi-Guaçu sample, which also showed a size heteromorphism between homologous. Besides, negatively stained sites $\left(\mathrm{CMA}_{3}^{-}\right)$were observed close to NORs (Fig. 4a). DAPI staining showed negative regions (DAPI-) corresponding to NORs while the chromosomal segment close to NORs $\left(\mathrm{CMA}_{3}{ }^{-}\right)$was stained with DAPI (Fig. 4 b).

All individuals analyzed from the tributaries of the rio Tibagi showed positive $\mathrm{CMA}_{3}$ staining coincident with AgNOR sites and also at the centromeric region of some metacentric chromosomes (Fig. 4c). DAPI- regions were observed corresponding to Ag-NORs in both samples from rio Tibagi basin (Fig. 4d).

Heterochromatin, detected by C-banding, was distributed at pericentromeric region of a metacentric pair and as large terminal blocks on long arms of two pairs (st-a), with heterochromatic segments adjacent to secondary constrictions in all individuals from rio Mogi-Guaçu sample (Fig. 5a). The same pattern was observed with DAPI- and $\mathrm{CMA}_{3}$-stained C-banding, with presence of fluorescent bands at terminal position on long arms of st-a chromosomes, although Ag-NORs could not be distinguished from heterochromatin (Fig. 5b and c).

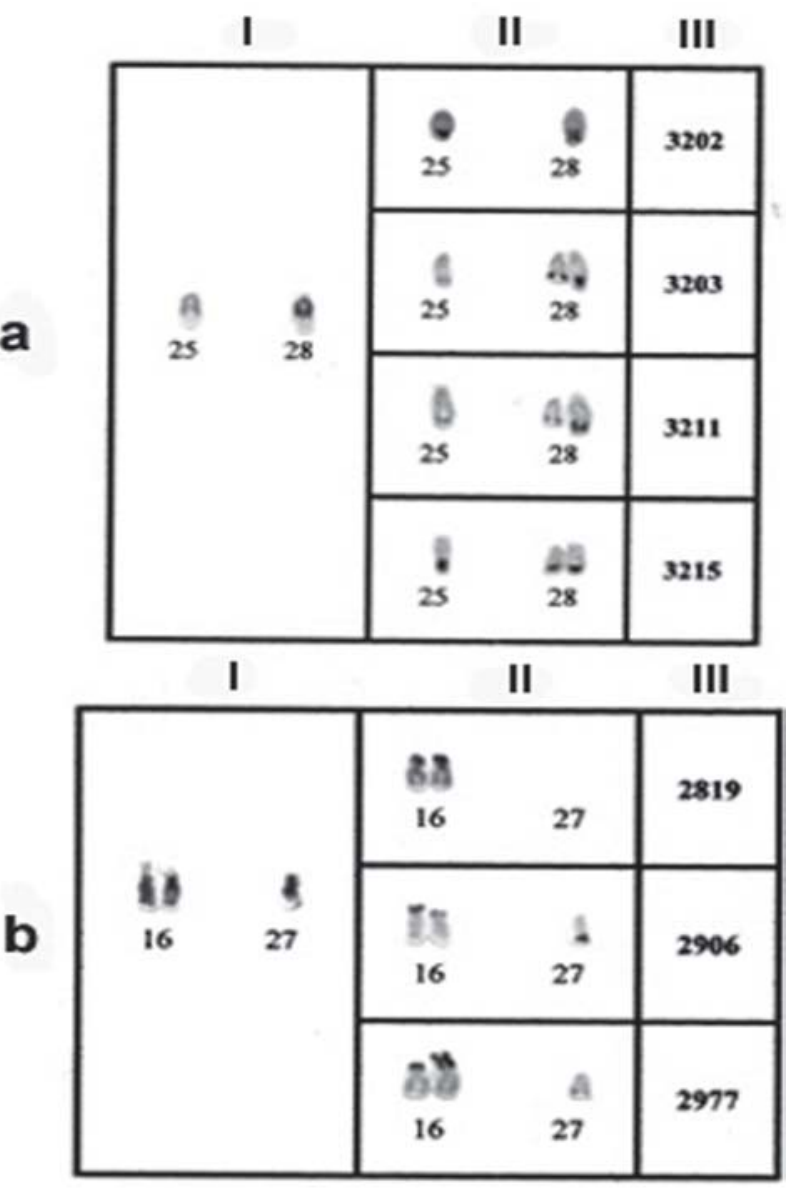

Fig. 3. Chromosomes bearing of Hypostomus nigromaculatus secondary constriction: $a=$ sample from rio Mogi-Guaçu and $\mathrm{b}=$ sample from tributaries of the rio Tibagi; I- Giemsa-stained; II- silver nitrate staining; III- number of specimens examined.
C-banded chromosomal preparations of individuals from both tributaries of rio Tibagi revealed heterochromatin blocks at terminal region on long arms of two st-a pairs, at centromeric region of several chromosomes and associated with Ag-NORs. The Ag-NOR-bearing chromosomal pair also showed size heteromorphism between homologous (Fig. 5d). C-banding stained with $\mathrm{CMA}_{3}$ presented fluorescent marks at terminal region of some st-a chromosomes, either on short or long arms, including Ag-NOR chromosomes (Fig. 5e). Cbanding with DAPI staining showed positive bands at centromeric region of two metacentric pairs and some negative sites corresponding to NORs (Fig. 5f).

\section{Discussion}

Conventional cytogenetic analysis of the three samples of $H$. nigromaculatus showed a same diploid number; but the specimens collected in the tributaries of rio Tibagi differed from those from rio Mogi-Guaçu in relation to FN and location of secondary constriction and Ag-NOR-associated heterochromatin. Changes in the karyotype formulae without modifications in the diploid number are usually determined by structural chromosomal rearrangements, such as pericentric inversions, along the karyotype evolutionary pathways of the group.

After silver nitrate staining, the chromosomes all individuals analyzed showed multiple NORs and a size heteromorphism between homologous, with distinct locations according to each sample. The specimens from rio Mogi-Guaçu presented terminal Ag-NORs on the long arms of three large st-a chromosomes; whereas the specimens from tributaries of the rio Tibagi presented Ag-NORs on the short arms of a large st-a pair and long arms of a small st-a chromosome, also terminally located.

As for the size heteromorphism of Ag-NOR sites in the samples from tributaries of the rio Tibagi, it is not known whether this feature is related to ribosomal cistrons or to heterochromatin amplification, since both are associated. Such Ag-NOR size polymorphism can be a consequence of unequal crossovers. This feature has been widely reported in other groups of Neotropical fish (Foresti et al., 1981; AlmeidaToledo et al., 2000) and it is also present within Loricariidae, such as Hypoptopomatinae (Andreata et al., 1994; Alves et al., 2003, 2006), Hypostominae (Artoni \& Bertollo, 1996) and Loricariinae (Giuliano-Caetano, 1998).

$\mathrm{CMA}_{3}$ staining detected sites corresponding to Ag-NORs, thus demonstrating that ribosomal sites in the three samples studied are GC-rich, as corroborated by the presence of DAPI negative bands.

The distribution of heterochromatin and its composition, determined by $\mathrm{CMA}_{3}$ and DAPI staining, also differed among samples. The rio Mogi-Guaçu sample showed both AT- and GC-rich heterochromatin segments, with large terminal blocks in two st-a pairs, including one NOR-bearing chromosomal pair. However, the sample from tributaries of the rio Tibagi 
showed a higher amount of heterochromatin widely distributed at centromeric and telomeric regions, and AgNORs. The heterochromatin associated with NORs was positively stained by $\mathrm{CMA}_{3}$ while DAPI stained centromeric region of two metacentric pairs.

According to Oliveira et al. (1988) and Almeida-Toledo et al. (1993), the migratory rate and population density can influence the karyotypic macrostructure of a group. That is, the greater the mobility and number of individuals of a group, the more stable the karyotypic macrostructure should be, since gene flow is higher and the fixation of some chromosomal alteration would be hindered. Most species of the genus Hypostomus are non-migratory and generally comprise small populations (Britski et al., 1984). Therefore, the differences observed among $H$. nigromaculatus samples in this study might be related to their populational structure.

The sample from rio Mogi-Guaçu has been geographically isolated, for a long time, from the tributaries of the rio Tibagi. Thus, the lack of gene flow between them would favor the fixation of distinctive modifications in both micro- and macrostructure in each sample, putatively resulting in an incipient speciation process.

Analogously, the karyotype similarity observed between samples from different tributaries of the rio Tibagi is likely related to the fact that both streams belong to the Tibagi river basin and they are geographically closer to each other.

Based on the results obtained in this work, samples from rio Tibagi basin and rio Mogi-Guaçu show considerable cytogenetic differences (FN, Ag-NOR location, and composition and distribution of heterochromatin). These differences corroborate previous reports, showing that this fish group is characterized by non-conserved features in relation to both chromosomal micro- and macrostructure (Michelle et al., 1977; Artoni \& Bertollo, 1996).

Nevertheless, regarding to external morphology, no apparent differences among the specimens from the three samples studied were observed, or these differences could be very subtle. Therefore, the samples studied could represent either distinct species but morphologically similar (cryptic species), or a single species, morphologically identical,
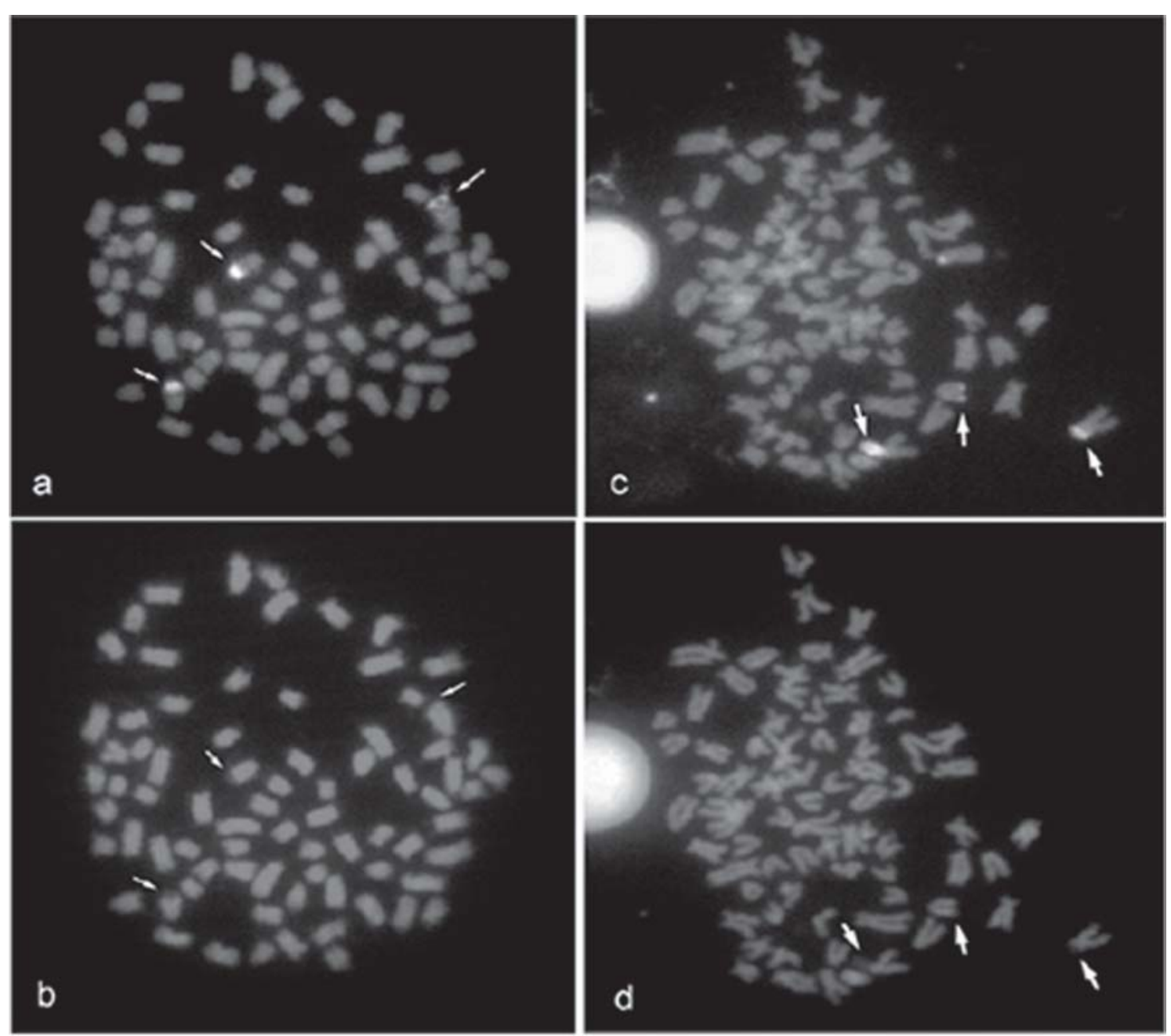

Fig.4. Metaphases of Hypostomus nigromaculatus stained with $\mathrm{CMA}_{3}$ and DAPI, respectively. a) and b): Mogi-Guaçu; c) and d): tributaries of the rio Tibagi. The arrows indicate the NORs. 
but showing a considerable intra-specific polymorphism. Cytogenetic studies focusing the population structure of Hypostomus species are not available so far. However, Zawadzki et al. (2002) analyzed two samples of $H$. margaritirer, one from the Itaipu reservoir and another from rio Corumbá, a tributary of rio Paranaíba using allozymes.
The authors found no diagnostic character but differences in the expected heterozygosity between populations, what they assumed to be due to a non-random mating system.

The genetic analysis of specimens from the type locality of those species known to be polymorphic can be a powerful tool to the taxonomic study of Neotropical fish. Such ap-
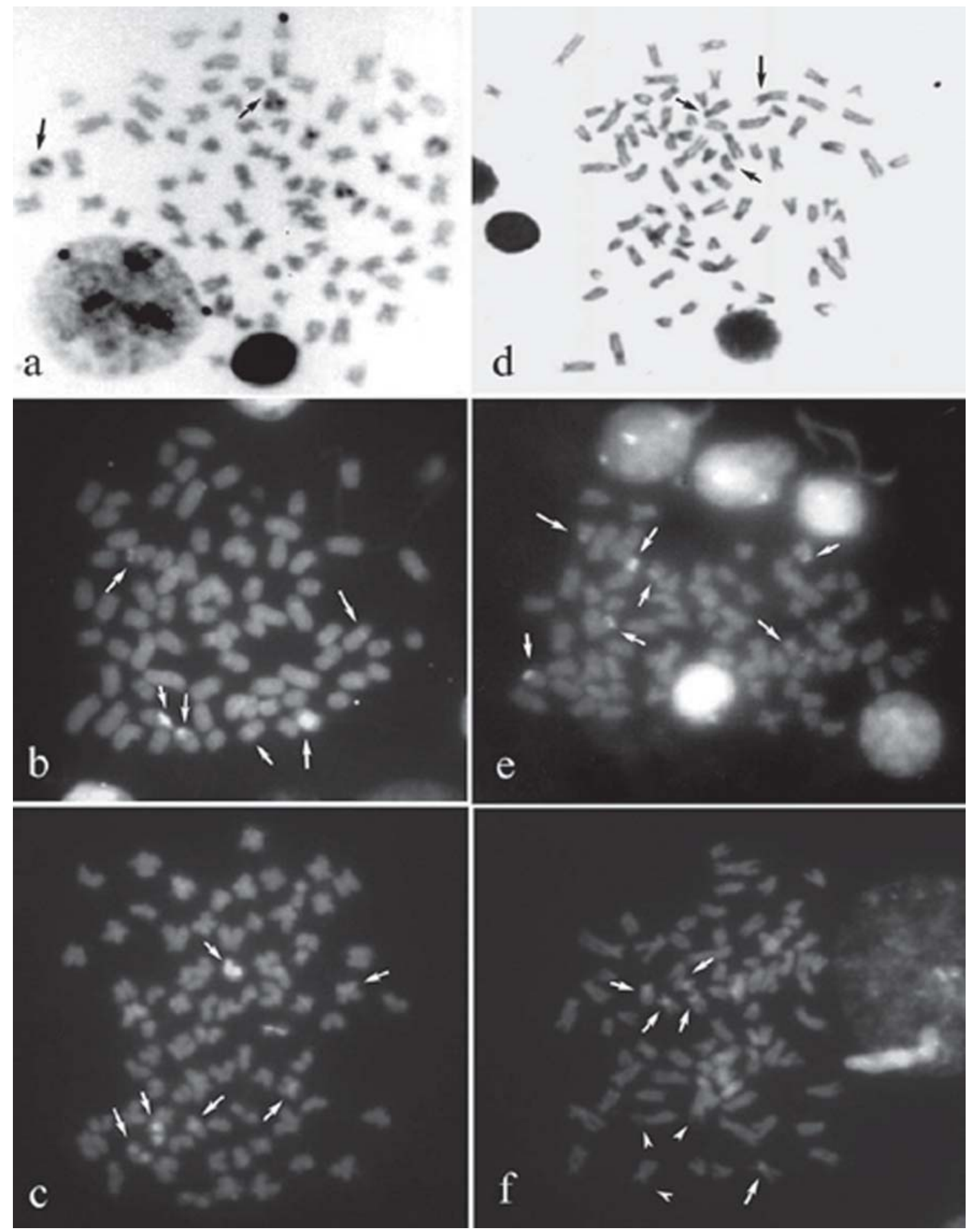

Fig. 5. C-banded metaphases of Hypostomus nigromaculatus stained with Giemsa, CMA and DAPI, respectively. a), b) and c): rio Mogi-Guaçu; d), e) and f): tributaries of the rio Tibagi. The black arrows indicate the NORs, the white arrows indicate heterochromatic blocks and the arrowheads indicate the negative bands. 
proach links cytogenetic, allozyme or molecular patterns to a specific taxon. When a population previously thought to belong to that taxon diverges considerably from the type locality, it should be taxonomically examined. Then, new questions can be raised, not only from an evolutionary genetic point of view, but also related to biogeographic and taxonomic issues.

In the present report, it should be pointed out that rio Mogi-Guaçu makes part of rio Grande basin and, just like rio Paranaíba, it presents a relatively differentiated ichthyofauna from the lower portion of the Upper Paraná river basin. Species such as Hypostomus fluviatilis (Schubart, 1964) and a new species of Hypostomus (C.H. Zawadzki and F. Langeani, pers. com.) from rio Grande, the characid Oligosarcus planaltinae (Menezes \& Géry, 1983), as well as the curimatid Steindachnerina corumbae (Pavanelli \& Britski, 1999), from the Paranaiba basin, are apparently limited to GrandeParanaíba basin. On the other hand, the Tibagi basin also presents a highly endemic fish fauna, as demonstrated by the recent description of two new loricariid species of the genus Isbruekerichthys (Jerep et al., 2006) in this region. Consequently, small populations of species and genera known to be polymorphic are expected to show some degree of genetic or morphological differentiation.

The cytogenetic differences among the samples analyzed here are remarkable but caution needs to be taken prior to determine whether these samples actually belong to the same species or not, since further additional studies on Hypostomus nigromaculatus are still required.

\section{Acknowledgments}

The authors are grateful to Prof. Dr. Horácio F. Júlio Jr and Prof ${ }^{\mathrm{a}} \mathrm{Dr}^{\mathrm{a}}$ Ana Lúcia Dias for suggestions on the manuscript preparation and CAPES and Fundação Araucaria for financial support. We are also thankful to Paulo Mello Affonso for his English assistance in the manuscript writing.

\section{Literature Cited}

Almeida-Toledo, L. F., F. Foresti, M. F. Daniel \& S. A. ToledoFilho. 1993. Nucleolar chromosome variants in Sternopygus macrurus (Pisces, Sternopygidae) from three Brazilian river basins. Caryologia, 46: 53-61.

Almeida-Toledo, L. F., F. Foresti \& S. A. Toledo-Filho. 2000. Karyotypic evolution in Neotropical freshwater. Chromosomes today, 13: 169-182.

Alves, A. L., C. Oliveira \& F. Foresti. 2003. Karyotype variability in eight species of the subfamilies Loricariinae and Ancistrinae (Teleostei, Siluriformes, Loricariidae). Caryologia, 56: 57-63.

Alves, A. L., C. Oliveira \& F. Foresti. 2005. Comparative cytogenetic analysis of eleven species of subfamilies Neoplecostominae and Hypostominae (Siluriformes: Loricariidae). Genetica, 124: 127136.

Andreata, A. A., L. F. Almeida-Toledo, C. Oliveira \& S. A. ToledoFilho. 1994. Cytogenetics studies on the subfamily Hypoptopomatinae (Pisces, Siluriformes, Loricariidae). III. Analysis of seven species. Caryologia, 47: 27-37.
Artoni, R. F. \& L. A. C. Bertollo. 1996. Cytogenetic studies on Hypostominae (Pisces, Siluriformes, Loricariidae). Considerations on karyotype evolution in the genus Hypostomus. Caryologia, 49(1): 81-90.

Artoni, R. F. \& L. A. C. Bertollo. 2001. Trends in the karyotype evolution of Loricariidae fish (Siluriformes). Hereditas, 134: 201-210.

Bertollo, L. A. C., C. S. Takahashi \& O. Moreira-Filho. 1978. Cytotaxonomic considerations on Hoplias lacerdae (Pisces, Erythrinidae). Brazilian Journal of Genetic, 1: 103-120.

Britski, H. A., Y. Sato \& A. B. S. Rosa. 1984. Manual de identificação dos peixes da região de Três Marias, Minas Gerais (com chave de identificação para os peixes da Bacia do São Francisco). 3a ed. Brasília, Câmara dos Deputados, Coordenação de Publicações-CODEVASF, Divisão de Piscultura e Pesca, 143p.

Christian, A., E. Mcniel, J. Roinson, R. Drabek, S. Larue, C. Waldren \& J. Bedford. 1998. A versatile image analysis approach for simultaneous chromosome identification and localization of FISH probes. Cytogenetic and Cell Genetic, 82: 172-179.

Foresti, F., L. F. Almeida-Toledo \& S. A. Toledo-Filho. 1981. Polymorphic nature of nucleolus organizer regions in fishes. Cytogenetic and Cell Genetic, 31: 137-144.

Giuliano-Caetano, L. 1998. Polimorfismo cromossômico Robertsoniano em populações de Rineloricaria latirostris (Pisces, Loricariidae). Unpublished Ph.D. Dissertation, Universidade Federal de São Carlos, São Carlos. 78 p.

Howell, W. M. \& D. A. Black. 1980. Controlled silver-staining of nucleolus organizer regions with a protective colloidal developer: a I-step method. Experientia, 36: 1014-1015.

Jerep, F. C., O. A. Shibatta, E. H. L. Pereira \& O. T. Oyakawa. 2006. Two new species of Isbrueckerichthys Derijst, 1996 (Siluriformes: Loricariidae) from the rio Paranapanema basin, Brazil. Zootaxa, 1372: 53-68.

Levan, A., K. Fredga \& A. A. Sandberg. 1964. Nomenclature for centromeric position on chromosomes. Hereditas, 52: 201-220.

Michelle, J. L., C. S. Takahashi \& I. Ferrari. 1977. Karyotypic studies of some species of the family Loricariidae (Pisces). Cytologia, 42: 539-546.

Montoya Burgos, J. I. 2003. Historical biogeography of the catfish genus Hypostomus (Siluriformes: Loricariidae), with implications on the diversification of Neotropical ichthyofauna. Molecular Ecology, 12: 1855-1867.

Oliveira, C., L. F. Almeida-Toledo, L. Mori, F. Foresti, H. A. Britski \& S. A. Toledo-Filho. 1988. Chromosome formulae of Neotropical Freshwater Fishes. Brazilian Journal of Genetic, 11: 577-624.

Reis, R. E., C. Weber \& L. R. Malabarba. 1990. Review of the genus Hypostomus Lacépède, 1803 from Southern Brazil, with description of three new species (Pisces, Siluriformes, Loricariidae). Revue suisse de Zoologie, 97: 729-766.

Scavone, M. D. P. \& H. F. Júlio Jr. 1994. Cytogenetic analysis and probable supernumerary chromosomes of Loricaria prolixa and Loricaria sp. Females (Loricariidae - Siluriformes) from the Paraná river basin. Revista de Ictiologia, 2/3 (1/2): 41-47.

Schaefer, S. A. 1987. Osteology of Hypostomus plecostomus (Linnaeus), with a phylogenetic analysis of the Loricariid subfamilies (Pisces, Siluroidei). Contributions in Science, Natural History Museum of Los Angeles County, 394: 1-31.

Schmid, M. 1980. Chromosome banding in Amphibia: IV. Differentiation of GC- and AT- rich chromosome regions in Anura. Chromosoma, 77: 83-103.

Schweizer, D. 1976. Reverse fluorescent chromosome banding with chromomycin and DAPI. Chromosoma, 58: 307-324. 
Souza, I. L. \& O. Moreira-Filho. 1995. Cytogenetic diversity in the Astyanax scabripinnis species complex (Pisces, Characidae). I. Allopatric distribution in a small stream. Cytologia, 60: 1-11.

Sumner, A. T. 1972. A simple techinique for demonstrating centromeric heterochromatin. Experimental Cell Research, 75: 304-306.

Weber, C. 2003. Subfamily Hypostominae. Pp 351-372. In Reis, R.E., S.O. Kullander \& C.J. Ferraris Jr. 2003. Check list of the freshwater fishes of South and Central America. Porto Alegre, Edipucrs, 742p.

Zawadzki, C. H., M. F. P. S. Machado \& E. Renesto. 2001. Differential expression for tissue-specific isozymes in three species of Hypostomus Lacépède, 1803 (Teleostei: Loricariidae). Biochemical Systematic and Ecology, 29: 911-922.

Zawadzki, C. H., E. Renesto, R. E. Reis, M. O. Moura \& R. P. Mateus. 2005. Allozyme relationships in hypostomines (Teleostei: Loricariidae) from the Itaipu Reservoir, upper Rio Paraná basin, Brazil. Genetica, 123: 271-283.

Zawadzki, C. H., C. Weber, C. S. Pavanelli \& E. Renesto. 2002. Morphological and biochemical comparison of two allopatric populations of Hypostomus margaritifer (Regan, 1907) (Osteichthyes, Loricariidae) from the upper Paraná River basin, Brazil. Acta Scientiarum, 24: 499-505.

Accepted December 2007

Published 31 March 2008 